\title{
Increased Osteoclasts
}

National Cancer Institute

\section{Source}

National Cancer Institute. Increased Osteoclasts. NCI Thesaurus. Code C147498.

An increase in the amount of osteoclasts. 